\title{
Moral Development of Junior High School Students about Environmental Issue of Riverbank by Problem Solving
}

\author{
Aminuddin Prahatama Putra \\ Biology Education Department \\ Universitas Lambung Mangkurat \\ Banjarmasin, Indonesia \\ aminuddinpatra@unlam.ac.id
}

\author{
Fitria Dina Zakia \\ SMA Muhammadiyah \\ Banjarmasin, Indonesia
}

\begin{abstract}
Nowadays, human's life cannot be separated from value, morality, and norm. Where there is human's life, there are value, morality, and norm included. Environmental issue in the riverbank is appointed as dilemmatic morality case and it can be used to find the characteristic of student's moral progress based on problem solving. The purpose of this research was to describe (1) students' moral progress levels on environmental issue in the riverbank by problem solving and (2) the characteristic of students' moral progress level on environmental issue in the riverbank by problem solving. Qualitative approach and descriptive research were used as the methods. The results of this research showed that students' moral progress levels on environmental issue in the riverbank by problem solving were categorized as level 2 and 5. The characteristics of junior high school students' moral progress level on environmental issue in the riverbank by problem solving were that the subjects in level 2 are likely to prioritize the real importance of each individual, but also respect the others' importance. The subjects in the level 5 of moral progress relatively hold the high esteem for the rule to regard the importance and the prosperity for all.
\end{abstract}

Keywords-Moral, Moral Development, Problem Solving.

\section{INTRODUCTION}

Moral issues, as well as moral teaching, or moral character today seem to be much talked about, especially in relation to the quality of human's moral character in this reformation era. Indonesian moral quality levels, in addition to facing the problem of ambiguous moral values that occur in the community, is also suspected toward the lowest level in the life of the nation [1].

The word moral always refers to the good and bad deeds of human as person. Moral is a belief about right and wrong, good and bad, in accordance with the social agreement, which underlies the actions or thoughts. Thus, the moral is associated with right and wrong things, good and bad things, belief, oneself, and social environments.

Moral development is divided into three levels: (1) preconventional, in which judgment is based solely on the needs and perceptions of one's own, (2) conventional, where the expectations of society and laws are taken into account, (3) the post-conventionally, where consideration is based on the principles of abstract and more personal and should not be determined by the laws of society [2].

Although the moral development is not determined by age, the rate of progress of human moral development at each stage can be qualitatively different [3]. Children who have stepped on puberty made a moral judgments based on equity, which is based on the ability of individuals to take responsibility for their behavior. Teens are no longer fixated on the fact that is concrete but have been able to consider the various possibilities that exist [4]. Science/IPA learning (including biology) has a large social and moral implications, which means no longer moral free, but rather tied to the moral [5].

Due to population growth that is increasingly out of control, an increase in the intensity of space causes an imbalance of structure and function, as well as disorganization of urban space. The city government of Banjarmasin since the end of 2014 until February 2015, is in full swing of demolition on the riverbanks, and also Tampekong River in Banjarmasin Veterans Road near to SMPN 6 Banjarmasin. Government's effort is certainly a real dilemma because on one hand, the aim is to restore the condition and function of the river around Banjarmasin city in relation to environmentally sustainable development. On the other hand, the riverbanks have been converted into a densely populated residential area. Even along the river is also polluted due to garbage that was discarded by people who are not responsible for it.

Many problems that ware caused by human activities and have the effect on the human themselves, such as environmental issues in river banks area. Those problems are one of the examples that need to be concerned on its solution

The completion of the problem always involved every corner of human activity, both in the fields of science, law, education, business, sports, health, industry, literature, and so on [6]. If there is no problem solving activity which is considered sufficient in professional and vocational life of our life, we can do a wide variety of repairment.

Problem solving is a basic process to identify problems, consider and determine problem solving options [7]. Therefore, there are steps in the process of problem solving. The steps of problem solving are as follows: 


\section{A. Understanding the problem}

Understanding the problem can be seen from how someone explains or defines the problem in their own words. Understanding the problem is initial activity to identify problems. In this step, people can list what is known and unknown in the problem, what is trying to be found or done in the matter, and any information that is relevant to the problem.

\section{B. Brainstorming all possible solutions}

After understanding the problem, someone can think broadly and creatively about ideas to solve problems and write down all the ideas that have been thought.

\section{Devising a plan}

At this stage, one has been able to analyze, synthesize, and organize ideas in the form of tables, diagrams, graphs, and so on. It is recommended to make a plan from a logical starting point and consider the source, intent, and purpose of the decision.

\section{Carrying out the plan}

The strategy which has been developed to solve the problem at the time of planning can be implemented at this stage. When carrying out the plan, each stage of the plan is observed and checked again.

\section{E. Evaluate the results}

In this evaluation phase, a solution analysis is done to the real problem. Then the relationship between the results and the problem will be seen, whether the result of the problem has been resolved or there is a change.

Students must understand the problem and have a desire to find a solution in solving the problem. Therefore, the problem should be chosen which is not too easy, not too difficult and interesting. If students can understand the problem, students can prepare the problem solving plan. Solving problems according to the problem solving plan requires knowledge, concentration on goals, and success. Examination of the steps and results is obtained by checking the truth of each statement used. If students work according to the plan, have written the solution of the problem, and check every step of the settlement, they will have enough reasons to convince that the solution is appropriate.

The purpose of this research was to describe the phase of students' moral development of SMPN 6 Banjarmasin towards environmental issue in the riverbanks through valid and reliable problem solving.

\section{METHOD}

The research was descriptive research with qualitative approach. The subjects consisted of two different classes who did Defining Issue Test (DIT) based on the theory by Lawrence Kohlberg. DIT consist of six stories of dilemma in biologymoral issue. The result of the test was expected to show a phase of moral development although it was not conducted through the stages of problem solving using written assignments.
Students who were selected to be the subjects of research were given a written assignment to carry out problem solving on the discourse of moral dilemmas by researchers for two rounds of appropriate material that has been studied by the subjects. Furthermore, analysis of the answer was held to get the data of moral development stage and the characteristic of students' moral development.

Interview was conducted to guarantee the data validity. The result of the interview was transcribed and combined with the written test of the subjects. If the obtained data were invalid, time triangulation was held by providing similar problem solving task and interview once again.

\section{RESUlt AND DISCUSSION}

Moral development is often aligned with a person's cognitive development. Therefore, to dig the stage of moral development of students, problem solving is needed. The problems that have been selected are the environmental issues on riverbanks. Subjects of this research with the results are as follows.

TABLE I. RESULT STAGE OF STUDENTS' MORAL DEVELOPMENT

\begin{tabular}{|c|c|c|}
\hline No & Subjects & Stage of Moral Development \\
\hline 1. & Subject $1(\mathrm{MF})$ & Stage 2 \\
\hline 2. & Subject 2 (MA) & Stage5 \\
\hline
\end{tabular}

\section{A. Subject 1 (MF)}

In the test of moral development (DIT), MF was at the stage 2 of moral development. To verify the results, a written assignment 1 was given with the result of the MF at the stage 2 of moral development according to Kohlberg because he can understand the problem with the orientation of the desire to be recognized as a good person, can think of possible solutions, can make plan but cannot implement the plans, and cannot evaluate the results. To reinforce the result, further assignment of written assignment 2 was given with the result of the MF at at the stage of moral development 2.

Characteristics of MF's moral development stage as the male subject was at the stage 2 of moral development. The data were obtained from the results of interviews based on written assignments 1 and 2 on MF.

Based on the result of written assignment interview 1, it can be said that MF can position himself with both roles that exist in written task discourse. It was seen when the researcher asked his opinion about the two figures in the written task.

M.F: In a written assignment 1, people are facing the problem of house evictions while the government insists that evictions remain in place. While on the written assignment 2, the problems faced by a man who fish with traditional fishing rods with small results, while his friends switch to use the stun device to get a lot of fish.

When understanding the problem, MF showed his orientation view toward others. When planning for problem solving, MF showed a view that is concerned with the needs 
of others. This was seen when he was asked if he was in a different position, according to the character in the written task.

$\mathrm{R}$ : If you are in between two positions, the people who have lived there for decades and the government who will displace the area to normalize the river function, which one will you choose? And why?

M.F : I choose to support the government because they want to restore the true function of the river and do a reforestation

$\mathrm{R}$ : Then on a written assignment 2, there was a man who stays at his stand by fishing using traditional tools and there are friends who turned to use practical methods of fishing using stun tools, which one do you choose? And why?

M.F: I agree with the actions of the man because it can keep the river ecosystem better. His friends should not force the man to come with them and never use the stun tool because it may damage to the ecosystem.

Based on the interview results of both written tasks, it can be said that MF can position himself with both roles that exist in the discourse. Based on the description of the characteristics of MF in understanding the problem, it can be concluded that MF understands the problem based on the views and principles of action and the action is judged good if it is without imposing the will and mutual respect among others.

\section{B. Subject 2 (MA)}

In the tests of moral development (DIT), MA was in stage 5 of moral development. In order to verify the results, a written assignment was given. Based on the results of the written assignment 1, MA was at stage 5 of moral development because she can understand the problem with the orientation of the desire to be recognized as a good person, be able to think of possible solutions, can plan, can implement the plan, and can evaluate the results. To reinforce the above findings, a written assignment 2 was given with the following results. Based on the results of written assignments 2 that have been done, MA was confirmed at the stage 5 of moral development.

Characteristics of MA's stage of moral development were obtained from the results of written based interviews tasks 1 and 2 on MA. Based on the results of the written assignment interview 1, it can be said that MA can position herself with both roles in the written task discourse. It was seen when the researcher asked her opinion about the two figures in the written task.

M.A : On the written task 1, the problem faced is the existence of evictions on the riverbanks by the city government of Banjarmasin. People who have been living in that area have objections and propose negotiations, but the government insisted on displacing the region. While on the written task 2, the problem faced is the confusion of a man who wants to maintain the river ecosystem by fishing using traditional fishing pole, but on the other hand many fishermen use stun tools to facilitate them to catch fish easier.

When understanding the problem, MA showed her orientation towards a personal opinion based on rights of social agreement. This was seen when she was asked if she was in a different position, according to the character in the written task.

$\mathrm{P} \quad$ : If you are in between two positions, the people who have lived there for decades and the government who will displace the area to normalize the river function, which one would you choose? and why?

M.A : I still choose to support the government, because many of the settlements in the riverbank area make the nature functions of the river changed. If the river function has changed, then the river ecosystem will be damaged. Make the rules so that no residents occupy the area, and maintain the cleanliness of the riverbanks. Although people should be forcibly evicted, it is the best option to make the river function normally again.

$\mathrm{P} \quad$ : Then on a written assignment 2, there was a man who stay at his stand by fishing using traditional tools and there are friends who turned to use practical methods of fishing using stun tools, which one do you choose? And why?

M.A : I also support the decision of the man. He is more concerned with the ecosystem and the people than himself. Although the income is small but still maintain the river ecosystem. Even he ignored his friend's invitation and still fishing with traditional fishing pole just to keep the ecosystem. Perhaps by making a pond to get lots of fish will to find another source to add his income.

Based on the results of the interview, it can be said that MA can position herself with both roles that exist in the written task discourse and can understand the problem to develop a plan with a personal opinion oriented based on rights of social agreement. Based on the description of the characteristics of MA in understanding the problem up to evaluating the results, it can be concluded that MA can conclude the solution to the real problem, check the outcome whether it has overcome the problem or has brought the change with a personal rights orientation in accordance with the social agreement.

Through written assignments and interviews, it can be seen that the stage of moral development of students based on problem solving was at the stage of moral development 2 and 5 according to Kohlberg. Table II shows the findings that refer to indicators of moral development [2].

TABLE II. INDICATORS OF JUNIOR HIGH SCHOOL STUDENTS' MORAL DEVELOPMENT BASED ON PROBLEM SOLVING

\begin{tabular}{|l|l|l|}
\hline $\begin{array}{c}\text { Moral } \\
\text { Development } \\
\text { Stage }\end{array}$ & \multicolumn{1}{|c|}{ Indicator } & \multicolumn{1}{c|}{ Description } \\
\hline Stage 2 & $\begin{array}{l}\text { Understand the } \\
\text { problem } \\
\text { Think of possible } \\
\text { solutions }\end{array}$ & $\begin{array}{l}\text { Students are able to understand } \\
\text { the problem with the profit- } \\
\text { oriented gain can think of } \\
\text { possible solutions, cannot plan, } \\
\text { cannot implement the plan,and } \\
\text { cannot evaluate the result. }\end{array}$ \\
\hline Stage 5 & $\begin{array}{l}\text { Understand the } \\
\text { problem } \\
\text { Think of possible } \\
\text { solutions } \\
\text { Devising a plan } \\
\text { Carry out the plan } \\
\text { Evaluate } \\
\text { results }\end{array}$ & $\begin{array}{l}\text { Students are able to understand a } \\
\text { problem with social agreement- } \\
\text { oriented, can think of possible } \\
\text { solutions, can plan, can } \\
\text { implement the plan, can evaluate } \\
\text { the result. }\end{array}$ \\
\hline
\end{tabular}


The stage 2 of moral development can be synchronized with Piaget's level of moral development in which rules and laws are made by human and when judging an act they consider its value and consequences. From Kohlberg's statement, at this stage the subject thinks if it is good to others then others will also be good, and the subject develops greater sensitivity to social conditions.

The stage 5 of moral development can be synchronized with Piaget's level of moral development that punishment is seen as an automatic consequence of offense. From Kohlberg's statement, at this stage the subject is aware of individual differences and opinions. Therefore, this stage is considered the stage that allows the achievement of consensus deliberation. This stage enables a person to see right and wrong as a matter of one's own values and opinions. At this stage, laws or rules can also be changed if it is better for the people.

Based on the data description by comparing the results of observation, written assignments, and interviews, these seven students were in the stages of moral development of 2 and 5 namely at the pre-conventional and conventional. This is in accordance with the opinion which states that the preconventional level is the level of most children under the age of 10 years [2]. The conventional level is the level of most teenagers and adults. While the post-conventional level is the level achieved by a sizable minority of adults. Stage 6 is included in the conventional post stage that is rarely achieved.

Moral dilemma requires careful consideration of the various problems of amoral dimension, and solved problems will exercise creativity in finding potential moral solution [8]. Similarly, the process of development of moral reasoning is a process over the role, which is a process of development towards a more comprehensive structure, more differentiated and more balanced than the previous structure [2] .

However, the researchers in field found that the assessment of problem solving ability of two different individuals does not merely refer to the individual at the same stage of moral development, or otherwise. Through moral dilemmas problem solving of environmental issues on the riverbanks which conducted by the students, it was found the orientation stage of moral development is at the stage of 2 and 5. Students in making morally oriented decision have advantageous terms and the desire to meet the environmental expectations. There are differences in the character of problem solving from each of the students and the differences characterize these findings.

Based on the results of the study, each stage of moral development produces different level of ability characteristics, where the higher stages of moral development, the more complex the characteristics obtained [9]. Subjects who are at stage 2 of development tend to be altruistic on real benefit of people, but also respect the others. The subjects who are at stage 5 of moral development relatively uphold the rule in the interests for all.

The formation process of moral behavior involves four key stages: (1) to interpret the situation in order to understand and discover what action that has to be done and how it affects the overall existing problems, (2) to describe what needs be done by applying a moral value in certain situations with the aim to establish a moral behavior, (3) to choose among moral values to decide what is going to do in actual ways, (4) to act according to moral values [10].

In terms of the ability to solve problems on discourse of moral dilemmas, the subjects at all stages of moral development have demonstrated the ability to understand the problem and think about possible solutions. Some of the subjects demonstrated an ability to plan, implement plans, and evaluate results. This shows that the problem solving is one of the most important ability and needs to be developed in the Biology teaching in junior high school. Problem solving is the process of applying the previous obtained knowledge into new situations that have not been known [11].

\section{CONCLUSIONS}

Stage of the moral development of junior high school students toward environmental issues on riverbanks through the problem solving was at the stage 2 (orientation relativistinstrumental), and stage 5 (the orientation of social agreement) which were valid and reliable.

Each stage of the moral development in this study was obtained to produce the characteristics of moral development stages of junior high school students toward environmental issues on river banks through problem solving with different results.

\section{REFERENCES}

[1] Sarbaini, Model Pembelajaran Berbasis Kognitif Moral dari Teori ke Aplikasi. Banjarmasin: Universitas Lambung Mangkurat Press, 2011.

[2] L. Kohlberg, Tahap-Tahap Perkembangan Moral. 1995. Transl. John de Santo and Agus Cremers. Yogyakarta: Kanisius, 1995.

[3] A. Budiningsih, Pembelajaran Moral Berpijak pada Karakteristik Siswa dan Budayanya. Jakarta: Rineka Cipta, 2013.

[4] R. Suciati, Perkembangan Moral Anak Tunggal pada Usia 15-18 Tahun. Jakarta: Universitas Gunadarma, 2009.

[5] J. R. Fraenkel, How To Teach About Values: An Analytic Approach. Prentice-Hall, Inc.Englewood Cliff. New Jersey. (Transl. Sarbaini and Fatimah), 1977.

[6] Solso, L. Robert, O. H. Maclin, and Maclin, M. Kimberly, Psikologi Kognitif. Jakarta: Erlangga, 2008.

[7] L. Greenstein, Assesing $21^{\text {st }}$ Century Skills: A Guide to Evaluating Mastery and Authentic Learning. USA: Corwin, 2012.

[8] S. K. Wolcott, 2000. Tutorial for optimizing and documenting openendedproblem solving skills [On-line]. Diunduh 12 Desember 2015 dari, Available: www2.apex.net/ users/leehaven., 2000.

[9] A. Prahatamaputra, "Indikator Penjenjangan Moral Menggunakan Tiga Teori Perkembangan Moral dalam Penyelesaian Masalah Biologi," Proceeding of National Seminar Year 2015 Science Education PPs Unesa Surabaya, January 2015. ISBN:978-602-72071-0-3., 2015.

[10] Kurtinez and Gerwitz, Handbook of Moral Behavior and Deveploment: Vol 2 Research, 1991.

[11] Kemendiknas, Pembelajaran Berbasis Masalah Matematika di SD: Modul Matematik SD Program Bermutu. Dirjen PMPTK. P4TK Matematika, 2010. 